\title{
Harvest and post harvest of mud crab (Scylla serrata) along Saurashtra coast of Gujarat
}

\author{
- Jitesh Solanki ${ }^{1 *}$, Prakash Parmar ${ }^{1}$, Hitendrakumar Parmar ${ }^{1}$, Anil Kotiya ${ }^{2}$, \\ HITESH PARMAR ${ }^{1}$ AND VANRAJ CHAVADA ${ }^{1}$ \\ ${ }^{1}$ College of Fisheries (J.A.U.), VERAVAL (GUJARAT) INDIA \\ ${ }^{2}$ Fisheries Training and Research Centre (J.A.U.), MAHUVA (GUJARAT) INDIA \\ Email : jitesh_jeet@yahoo.com
}

*Author for Correspondence

Research chronicle : Received : 27.09.2016; Revised : 12.10.2016; Accepted : 13.11.2016

\begin{abstract}
SUMMARY :
Mud crab is known as "Dhebaro" among coastal communities in Saurashtra region of Gujarat. Scylla populations are abundantly found in mangrove areas hence, they are also called mangrove crabs. In Gujarat, mud crabs are found in large quantity along Jamnagar district and in small quantity along Devbhumi Dwarka, Porbandar, Gir Somnath, Diu and Amreli coast of Saurashtra. Collecting gears commonly used in Saurashtra are stake net, scoop net type trap, gill net, cast net, hook and line and iron rod. Although mud crabs are caught throughout the year, the peak season is from July to September. About $1.5 \mathrm{~kg}$ Scylla serrata was captured in Okha coastal area in November 2010. Mud crabs collected from the natural habitat are brought to the landing sites for both domestic and export markets. The price of mud crabs in Saurastra coast differs depending on the area. In domestic market, the price of mud crab below one kg ranges from Rs. 110 to Rs. 300 per kg. Frozen mud crab meat and live mud crabs are exported to Singapore. S. serrata is more in demand in domestic market and also commands a better price compared to other species of mud crab.
\end{abstract}

KEY WORDS : Mud crab, Marketing, Saurashtra coast, Gujarat

How to cite this paper : Solanki, Jitesh, Parmar, Prakash, Parmar, Hitendrakumar, Kotiya, Anil, Parmar, Hitesh and Chavada, Vanraj (2016). Harvest and post harvest of mud crab (Scylla serrata) along Saurashtra coast of Gujarat. Internat. J. Proc. \& Post Harvest Technol., 7 (2) : 199-203. DOI: 10.15740/HAS/IJPPHT/ 7.2/199-203. 